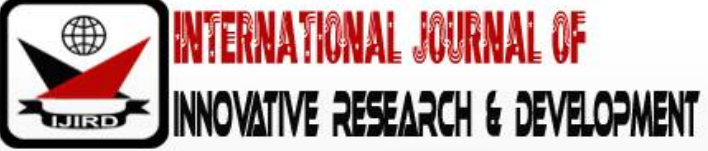

ISSN 2278 - 0211 (Online)

\section{Trauma of the First World War through Expressionism: A Study of the Cabinet of Dr. Caligari}

\author{
Risala Ahmed \\ Lecturer, Department of English, American International University, Bangladesh \\ Shihab Saqib \\ Lecturer, Department of English, American International University, Bangladesh
}

\begin{abstract}
:
In post-World War I Germany, expressionism appeared as a dominant style of artistic expression adapting itself to the atmosphere of cynicism, alienation and disillusionment which was prevalent at that time. With clear impact on art and literature, the movement also found a defining premise for itself in cinema. During the Weimar government's rule cinema represented the inner thoughts and fear of the German people through expressionism. Expressionism, explained by John Titford, "must always be mimetic, symbolic, and can never be the thing it represents" (n.d.).The Cabinet of Dr. Caligari (1920) through its expressionist mise en scene is one of the first films to successfully experiment this art style and has become textbook material for studying expressionism. The study will attempt to analyze different aspects of the film The Cabinet of Dr. Caligari (1920) including use of mise en scene, characterization and the thematic illustration to symbolically represent the trauma of the first Great War.
\end{abstract}

Keywords: Expressionism, World War I, German Cinema, Mise in Scene

\section{Introduction}

Prior to the World War I, German films fell firmly within the established idea of a "cinema of attraction." -they were spectacles designed for entertainment. In 1917, the German military supreme command took control of all the major film studios. The idea was to centralize all the film talent, equipment, and facilities in the country, and to focus on nationalist films - a pro-German, pro-government cinema that would help them win the war. In the aftermath of the war, imperial rule ended and a national assembly in the city of Weimar gave birth to a new republican government. This era in German history is marked by hyperinflation, political extremism, violence, and deeply troubled relationships with the countries that had won the war. However, Germany did still have a great infrastructure for film production and distribution that actually grew during the war, while the rest of the economy went into a free fall. As the rest of Europe's film industry was nearly decimated, by 1920, Germany had the only film industry in the world able to compete with Hollywood. Although the state-sponsored and state-controlled agency UFA (Universum Film-Aktien Gesellschaft) had control over all the major film studios, a few independent production companies persisted. The cinema made by these companies became a medium of the symbolic representation of the uncertainty and dread that was the byproduct of the Weimar republic. One such production house, Decla, knew they could not compete with UFA in terms of scale or resources. The producers understood they had to do something out of the ordinary to attain public attention. Their breakout film, The Cabinet of Dr. Caligari (1920) reshaped the German film style, and eventually influenced the look and tone of several Hollywood genre movies.

While propaganda films, escapist comedies and light historical dramas were filling rapidly expanding theatres, the horror genre experienced a rebirth amongst filmmakers needing an outlet for revolutionary energy, who saw its potential as a medium for reflecting the inner fears and unrest in their audiences with films like Robert Weine's The Cabinet of Dr. Caligari(1920) and The Golem(1920). This new movement revolved around stage producer Max Reinhardt, who oversaw Berlin's Deutsches Theatre, and introduced to theatre-goers dramatic devices we know now and label as "Expressionist," like exaggerated acting motions and extreme contrasts of light and shadow (Eisner 47). Germany's deflated currency actually served as an advantage for UFA, the powerhouse production studio which would employ directors like Murnau and Fritz Lang: making a film cost a mere fraction of what, for example, Italy or France did on its filmic outputs (Elsaesser 197).

The Cabinet of Dr. Caligari (1920) was thematically based on the experiences of the writers Hans Janowitz and Carl Mayer as soldiers in World War I and their distrust of authoritarian leadership. The film tells a story of a young German man who comes across a strange individual Dr. Caligari and his Somnambulist, a man in an eternal state of sleep who can be ordered to perform his master's commands. A sequence of horrific murders soon takes place, causing speculations about the Doctor and his Assistant's involvement. The themes of authority and conformity in The Cabinet of Doctor Caligari (1920) are both a reflection on post-world War One Germany and that disturbing foreshadowing of what was to come. 
Features representing such oppressive authority of the Weimar Republic can be traced Siegfried Kracauer's influential book on Weimar cinema, From Caligari to Hitler (1947). Kracauer connects the political events of the Weimar Republic to films that were released during the time, focusing on the importance of popular culture in shaping modernity under social, political and economic conditions. Kracauer claimed this on the theory that the Weimar cinema directly reflected the mentality of the German people and the foreshadowing rise of Hitler:

"In recording the visible world- whether current reality or an imaginary universe- films therefore provide clues to hidden mental processes." (Kracauer, 1947)

Kracauer's comparison to the repressed inner soul and tyranny of the society of Weinner explains the expressionist display of the post-war psyche. The book documents the progressive anxiety, repression and disavowal that may have formed the disposition of the German people during a period of rapid change.

Expressionist theory focused on the subjective nature of aesthetic experience, and privilege intuition, emotional response and expression over reason and rationality. Expressionism also shared a very modern concern for exploring the language of art, and this led the artists to use visual distortion as a part of the attempt to move away from nature, back to the picture. This led to the emergence of an artistic practice characterized by the foregrounding of formal devices, and with distorted, antirealist, violent and forceful imagery, indicating chaos in the process. (fig. 2)The Cabinet of Dr. Caligari is the first to use surrealistic production design in a major way and is considered a key work of the Expressionist movement of the post war Germany. The brilliant expressionist mise-en-scene or arrangement of sets, scene and use of props create a quasi-surrealistic world that showcased all the actions in distorted appearance with deliberate detachment from reality. Actions are shrouded in shadows, which add to grim atmosphere that is felt from the very onset of the film. This is the heart of German Expressionism, using an exaggerated, distorted mise-en-scene to reflect the inner psychology of the characters giving the audience a subjective view from the perspective of the characters.

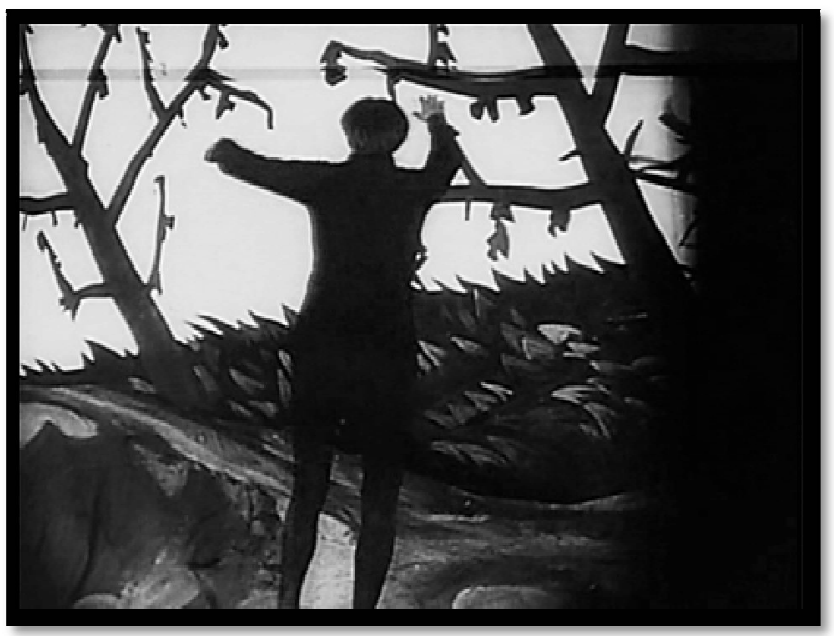

Figure 1: Landscapes with Jagged Spikes

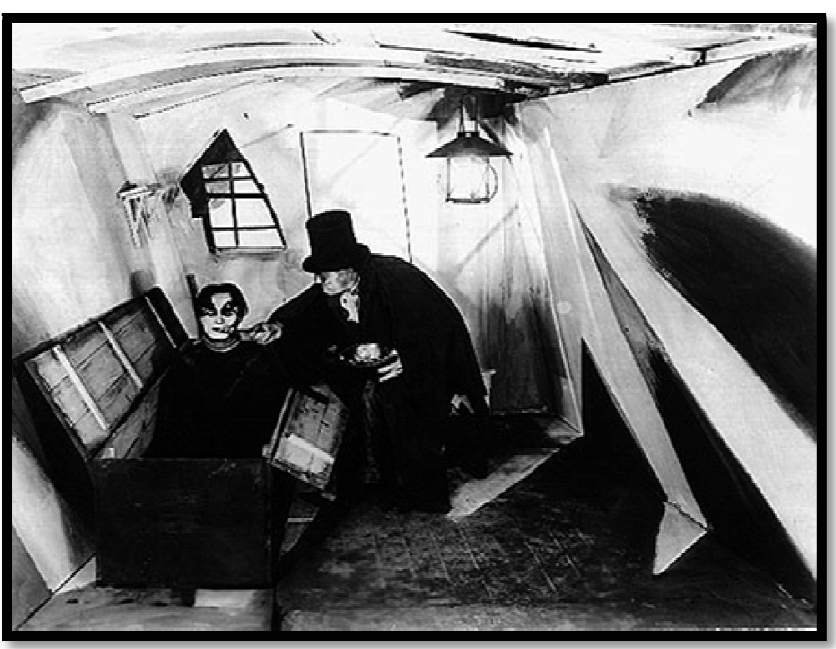

Figure 2: Distorted Perspective

The Cabinet of Dr. Caligari, more-so than other early Weimar films, portrays this idea of Expressionism in the natural world where it seems to be against those who inhabit it, with the grass and leafless trees shaped like spears (fig. 1). Chaos here is more directly related, as it is through the visions of a madman that this nature is depicted. According to Hermann Warm, the art director, it was Walter Reimann who suggested that the story of Caligari should be presented in an Expressionist style. As Warm recalls he himself had recognised that the design of the film had to deviate from the usual naturalist style. The film images had to be given a fantastic, graphic design turned away from the real. The images had to be visionary, nightmarish. Erich Pommer has also come out and taken credit for the films Expressionist set design. 
Pommer, the film's producer, had an excellent knowledge for cinematic values and popular demands, and during the early postwar years, the foreign markets could only be conquered by artistic achievements. Regardless of whether he grasped the significance of the story, he certainly sensed its timely atmosphere and scenic potentialities. This interpretation has led to the allegation that films such as Caligari were not so much authentic works of art, but more the outcome of product differentiation within commercial cinema. Regardless of the commercial potential, the film exerts a desired emotional effect on the audience that represents the environment as being against those who inhabit it in nature, as felt by the people of Weimar Germany.

The meaning behind Expressionism is evident in the name itself. It is a highly psychological form of art that seeks not to record what is happening in the outside world, but to express what is happening on the inside, within the mind of the individual. Expressionism seeks to access an interior world characterized by garish and unnatural colors, jagged lines, and sharp distinctions between color spheres. The Cabinet of Dr. Caligari reflects these aspects through its artistic display of mise en scene, characterization and thematic portrayal of the horror of war ravaged, shell shocked, disillusioned dystopic society as the study have attempted to show. Ironically the film also foreshadows the eminent horrors that are to befall the nation. The influence and impact of The Cabinet of Dr. Caligari on expressionist style have not only been contemporary but transcended time and context ever since.

\section{References}

i. Eisner, Lotte. The Haunted Screen: Expressionism in the German Cinema and the Influence of Max Reinhardt. University of California Press, 2008.

ii. Elsaesser, Thomas. Weimar Cinema and After: Germany's Historical Imaginary. Routledge, 2000.

iii. Kracauer, Siegfried. From Caligari to Hitler: A Psychological History of the German Film. Edited by Leonardo Quaresima, Princeton University Press, 1947.

iv. Titford, John S. "Object-Subject Relationships in German Expressionist Cinema." Cinema Journal, vol. 13, no. 1, pp. 17-24.JSTOR. DOI: $10.2307 / 1225056$.

\section{Appendix}

The Cabinet of Dr. Caligari (Das Cabinet des Dr. Caligari, 1920)

Directed by: Robert Weine

Produced by: Rudolf Meinert, Erich Pommer

Written by:Hans Janowitz, Carl Mayer

Cinematography by:Willy Hameister

Starring:Werner Krauss, Conrad Veidt, Friedrich Fehér 